\title{
Spatial Distribution Pattern of Longhorn Beetle Assemblages (Coleoptera: Cerambycidae) in Mongolian Oak (Quercus Mongolica) Forests in Changbai Mountain, Jilin Province, China
}

Shengdong Liu

Beihua University

Xin Meng

Beijing Forestry University

Yan Li

Beihua University

Qingfan Meng ( $\nabla 008175 @ q q . c o m)$

Beihua University https://orcid.org/0000-0003-3245-7315

Hongri Zhao

Beihang University

Yinghua Jin

Northeast Normal University

\section{Research}

Keywords: longhorn beetles, topographic condition, vertical height, Mongolian oak forest, Changbai Mountain

Posted Date: August 17th, 2021

DOI: https://doi.org/10.21203/rs.3.rs-795304/v1

License: (1) This work is licensed under a Creative Commons Attribution 4.0 International License. Read Full License 


\section{Abstract}

Background: Mongolian oak forest is a deciduous secondary forest with a large distribution area in the Changbai Mountain area. The majority of longhorn beetle species feed on forest resources, The number of some species is also large, which has a potential risk for forest health, and have even caused serious damage to forests. Clarifying the distribution pattern of longhorn beetles in Mongolian oak forests is of great scientific value for the monitoring and control of some pest populations.

Methods: 2018 and 2020, flying interception traps were used to continuously collect longhorn samples from the canopy and bottom of the ridge, southern slope, and northern slope of the oak forest in Changbai Mountain, and the effects of topographic conditions on the spatial distribution pattern of longhorn beetles were analyzed.

Results: A total of 4090 individuals, 56 species, and 6 subfamilies of longhorn beetles were collected in two years. The number of species and individuals of Cerambycinae and Lamiinae were the highest, and the number of Massicus raddei (Blessig), Moechotypa diphysis (Pascoe), Mesosa myopsmyops (Dalman), and Prionus insularis Motschulsky was relatively abundant. Topographic conditions did not affect the vertical distribution of richness and abundance of longhorn beetles in the forest, but topographic conditions and vertical height independently affected the composition and quantity of the beetle assemblages. The community composition of longhorn beetles in the forest bottom and canopy was significantly different, and the richness and abundance were higher in the canopy under good light conditions. Cerambycinae and Lamiinae preferred to be active in the canopy, Prioninae preferred to be active in the forest bottom, and Lepturinae did not show any difference in the bottom and the canopy.

Conclusions: The composition of the longhorn beetle community on the ridge was significantly different from that on the southern slope and the northern slope, and the richness and abundance on the ridge and the southern slope were higher than those on the northern slope. Different species had different preferences for topographical conditions and vertical height, which indicated the adaptability of longhorn beetles in the forest.

\section{Introduction}

The longhorn beetles (Cerambycidae) are a large group in Coleoptera, with 35,000 known species worldwide (Svacha and Lawrence 2014). Longhorn beetles are widely distributed in the forest and feed on tree branches and trunks. A few species can cause serious harm to trees (Ji et al. 2002). Some species feed on dead and decayed wood and are important decomposers and important ecological factors in the process of tree decay (Linsley 1961; Speight 1989; Alexander 2008). After the trees in the forest die, some longhorn beetles move in quickly and play an important role in accelerating the decomposition of dead and decaying wood (Buse et al. 2008, Ulyshen 2016). They play an important role in promoting forest ecosystem material circulation and forest regeneration (Sirami et al. 2008; Wende et al. 2017; Hammond et al. 2017). Some species have the habit of visiting flowers and are important pollinators and media for the survival and reproduction of plants (Gao et al. 2005; Guo et al. 2012; Meng et al. 2013). At the same time, 
some species are sensitive to environmental changes and can be used as biological indicator species (Karpiński et al. 2021).

Longhorn beetles are herbivorous insects, and vegetation type affects the composition and diversity of longhorn assemblages (Noguera et al. 2002; Gao et al. 2014; Wang et al. 2016). Most species of longhorn beetles strongly correlate with forest type (Yotkham et al. 2021). Forests are important habitats for longhorn beetles. Forest composition, forest management, forest fire, environmental change, and spatial heterogeneity all affect the distribution of longhorn beetle diversity (Toledo et al. 2002; Ohsawa 2004; Eliott et al. 2019). Stand type, stand age, composition, sectional area, diameter at breast height (DBH), and dead wood affect the richness and abundance of longhorn beetles (Grove 2002; Saint-Germain et al. 2006; McGeoch et al. 2007; Boucher et al. 2012; Lassauce et al. 2013; Boulanger et al. 2013). The host specificity affected the longhorn beetle community assemblage (Luo et al. 2021). Stands with complex tree species composition and structure and a large variation in diameter class or age structure can provide more diversified food resources for longhorn beetles (Buongiorno 1994), and some species prefer to live in stands with large DBH (Casula et al. 2021). The richness of longhorn beetles is positively correlated with the number of tree species, and the abundance is positively correlated with the number of trees. The richness and abundance of longhorn beetles are relatively high in natural forests (Meng et al. 2013).

With the improvement of survey methods in recent decades, some researchers have begun to realize that the forest canopy is an important habitat for insects, and some in-depth studies have been conducted (Kato et al. 1995; Su et al. 2001; Ulyshen et al. 2007, 2010; Sugimoto and Togashi 2013; Schmeelk et al. 2016). The canopy is an important habitat for the distribution of longhorn beetles due to sufficient light, which can provide different community structures and environmental conditions relative to the lower layer (Weiss et al. 2016; Miller et al. 2020). The diversity and richness of longhorn beetles increased with the increase in vertical height, but the abundance of longhorn beetles did not differ significantly in the area higher than $5 \mathrm{~m}$ above the ground in the forest (Ulyshen et al., 2019). Longhorn beetles have a certain distribution pattern in the forest and a high diversity in the canopy (Vance et al. 2003; Engelken and Mccullough 2020). Longhorn beetles are more inclined to the forest bottom of some forests with low plant diversity (Ulyshen 2011). However, this distribution pattern will also change with time and changes in the external and internal environmental conditions (Lee et al. 2014).

The application of flying interception traps can collect specimens throughout the day during the whole active period of longhorn beetles, greatly improving the collection efficiency and promoting the in-depth study of longhorn beetle communities in the forest (Hanks 2012; Lamarre et al. 2012; Rassati et al. 2020). Although more research results have been obtained on the distribution pattern of longhorn beetles in stands, there are still a few studies on the effect of topographic factors on the spatial distribution of longhorn beetles. Quercus mongolica forest is a natural secondary forest with the largest distribution area and growing stock volume in Jilin Province. However, the species composition, the vertical distribution pattern of longhorn beetles in the forest, and the effects of topographic factors such as ridges and different slope aspects on the distribution pattern of longhorn beetles are still unclear, which restricts the monitoring of longhorn beetle assemblages and major pests. In this study, longhorn beetles were collected 
continuously throughout the active adult period to reveal the species distribution pattern and influential factors of longhorn beetle in a Mongolian oak forest. This study also provided a basis for the conservation of insect diversity, monitoring and control of the outbreak of dangerous longhorn beetles, exploration of the response of longhorn beetles to forest environmental changes, and the conservation and utilization of diversity of environmentally sensitive species. The main aims included: (1) determination of the species composition of longhorn beetles in the oak forest and (2) determination of the vertical distribution pattern of longhorn beetles in the oak forest and the effect of topographic condition on the vertical distribution of longhorn beetle assemblages.

\section{Study area}

The study area was located in Dashi Village, Jilin city, Jilin Province, with a geographical location of $126^{\circ} 51^{\prime} 34^{\prime \prime} \mathrm{E}, 43^{\circ} 33^{\prime} 45^{\prime \prime} \mathrm{N}$. The vegetation belongs to the flora of Changbai Mountain, and the main stand type is natural secondary forest, i.e., Mongolian oak forest. The main tree groups taxa Quercus mongolica Fischer ex Ledebour, Fraxinus rhynchophylla Hance, Acer mono Maxim, Tilia amurensis Rupr. Tilia mandshurica Rup et Maxim., and Armeniaca sibirica L. The region has the following characteristics: a temperate continental monsoon climate, four distinct seasons, little rain, dry and windy in spring, warm and rainy in summer, cool in autumn, and cold and snowy in winter. The annual average temperature is 3$5^{\circ} \mathrm{C}$; the lowest temperature can reach $-35^{\circ} \mathrm{C}$, and the highest is $38^{\circ} \mathrm{C}$. The annual sunshine duration is $2400-2600 \mathrm{~h}$, and the average annual precipitation is $700-800 \mathrm{~mm}$, mostly concentrated from June to August. The first frost usually occurs in late September.

\section{Materials And Methods}

\section{Sample setting}

We selected one Mongolian oak forest stand of about 4 ha as the study stand. The average height of the stand was about $17 \mathrm{~m}$, and the slope of the southern and northern slopes was about $22^{\circ}$. Quercus mongolica was the main tree species with a canopy density of about 0.7. We used RTK (GNSS 180) to locate the position and elevation of each tree and determined the tree species and DBH of each tree in the sample (Table 1).

Table 1 The tree species composition of plots on the ridge, southern slope, and northern slope 


\begin{tabular}{|c|c|c|c|c|c|c|}
\hline \multirow[t]{2}{*}{ Positions } & \multirow[t]{2}{*}{ Tree species } & \multirow[t]{2}{*}{$\mathrm{DBH}$} & \multicolumn{2}{|c|}{ Tree number } & \multicolumn{2}{|c|}{ Stand basal area } \\
\hline & & & Number & $\%$ & Area $\left(\mathrm{cm}^{2}\right)$ & $\%$ \\
\hline \multirow[t]{10}{*}{ On the ridge } & Quercus mongolica & 21.4 & 440 & 60.60 & 169744.9 & 72.17 \\
\hline & Tilia amurensis & 15.8 & 93 & 12.81 & 20985 & 8.92 \\
\hline & Acer mono & 11.0 & 76 & 10.47 & 8567.9 & 3.64 \\
\hline & Fraxinus rhynchophylla & 14.5 & 47 & 6.47 & 8589.2 & 3.65 \\
\hline & Pinus tabulaeformis & 28.6 & 22 & 3.03 & 16090.4 & 6.84 \\
\hline & Betula dahurica & 20.0 & 19 & 2.62 & 6427.7 & 2.73 \\
\hline & Sorbus alnifolia & 13.4 & 12 & 1.65 & 1810.6 & 0.77 \\
\hline & Larix kaempferi & 14.0 & 6 & 0.83 & 1016.4 & 0.43 \\
\hline & Other trees & 12.0 & 11 & 1.52 & 2010.7 & 0.85 \\
\hline & Total & 16.7 & 726 & 100 & 235242.8 & 100 \\
\hline \multirow[t]{9}{*}{ On the southern slope } & Quercus mongolica & 20.6 & 419 & 58.6 & 165975.9 & 79.94 \\
\hline & Acer mono & 10.2 & 116 & 16.22 & 10254 & 4.94 \\
\hline & Tilia amurensis & 12.3 & 72 & 10.07 & 10664.3 & 5.14 \\
\hline & Fraxinus rhynchophylla & 10.9 & 52 & 7.27 & 6797.5 & 3.27 \\
\hline & Tilia mandshurica & 13.2 & 15 & 2.1 & 2454 & 1.18 \\
\hline & Pinus tabulaeformis & 24.9 & 14 & 1.96 & 8761 & 4.22 \\
\hline & Ulmus davidiana & 8.6 & 13 & 1.82 & 820.9 & 0.40 \\
\hline & Other trees & 15.7 & 14 & 1.96 & 1890 & 0.91 \\
\hline & Total & 14.6 & 715 & 100 & 207617.6 & 100 \\
\hline \multirow[t]{8}{*}{ On the northern slope } & Quercus mongolica & 22 & 144 & 27.70 & 58499.4 & 37.52 \\
\hline & Tilia amurensis & 17.7 & 110 & 21.15 & 27022.3 & 17.34 \\
\hline & Fraxinus rhynchophylla & 16.1 & 89 & 17.12 & 22592.8 & 14.50 \\
\hline & Acer mono & 13.2 & 80 & 15.38 & 13817.1 & 8.87 \\
\hline & Tilia mandshurica & 14.6 & 26 & 5 & 4971.5 & 3.19 \\
\hline & Betula dahurica & 29.8 & 26 & 5 & 15090.1 & 9.68 \\
\hline & Armeniaca sibirica & 15.6 & 9 & 1.73 & 2401.4 & 1.54 \\
\hline & Sorbus alnifolia & 11.4 & 8 & 1.54 & 923.5 & 0.59 \\
\hline
\end{tabular}




\begin{tabular}{llllll} 
Pinus tabulaeformis & 25.8 & 5 & 0.96 & 2708.2 & 1.74 \\
\hline Betula platyphylla & 31.5 & 5 & 0.96 & 4097.1 & 2.63 \\
\hline Other trees & 16.3 & 18 & 3.46 & 3734.3 & 2.40 \\
\hline Total & 19.5 & 520 & 100 & 155857.7 & 100
\end{tabular}

\section{Specimen collection}

In the forest, 48 sample plots were set according to topographic conditions, and the distance between each plot was greater than $30 \mathrm{~m}$. Flying interception traps were set in each canopy and bottom to collect longhorn beetle specimens, and no lure was placed in the trap. We use a rope to hang the traps on the branches of the canopy 13-15 $\mathrm{m}$ above the ground. The bottom traps were suspended between two trees by iron wire at a distance of more than $1 \mathrm{~m}$ from the trunk. The collection cups of the trap were about 30 $\mathrm{cm}$ from the ground. The cup was filled with saturated saline to prevent the specimen from decaying. A low amount of odorless detergent was added to reduce the surface tension of the water and facilitate the sinking of the specimen to the bottom of the cup. A total of 96 traps were set in the sample plot, i.e., 48 in the canopy $(H), 48$ in the bottom $(L)$. Of the 96 traps, 32 were located on ridges $(A), 32$ were located on the southern slope (B), and 32 were located on the northern slope (C) in the forest (Table 2).

\section{Table 2 Flying interception trap location information}

\begin{tabular}{|llll|}
\hline Trap position & Ridge (A) & Southern slope (B) & Northern slope (C) \\
\hline Canopy $(\mathrm{H})$ & $\mathrm{AH}$ & $\mathrm{BH}$ & $\mathrm{CH}$ \\
\hline Bottom $(\mathrm{L})$ & $\mathrm{AL}$ & $\mathrm{BL}$ & $\mathrm{CL}$ \\
\hline
\end{tabular}

\section{Specimen collection and preservation}

In 2018 and 2020, traps were set up in the survey stands from May 15 to September 15 each year. The longhorn beetle specimens were collected every 2 weeks. In the case of rainy days, the collection time was extended. The collected specimen was put into the sample bag and transported to the laboratory. After each collection, the collection cup was filled with salt, water, and detergent. The specimens were made by needle insertion to facilitate long-term preservation in the laboratory. All of the insect specimens were preserved in the Insect Laboratory of the College of Forestry, Beihua University.

\section{Data analysis}

MANOVA was used to analyze the effect of topographic conditions on the vertical height distribution of the longhorn beetle's richness and abundance. The Friedman test was used to determine the difference in richness and abundance with respect to the topographic condition and vertical height. Estimates 9.1 software was used to calculate the rarefaction curve of the species distribution pattern under different topographic conditions and vertical heights (Solow and Roberts 2006; Colwell 2013). Finally, we performed non-metric multidimensional scaling to show differences in the composition of longhorn beetle 
assemblages at the two vertical heights and along the three slopes by using PC-ORD (McCune and Mefford 2011). The autopilot mode of PC-ORD was used to conduct this analysis using the Bray-Curtis distance measure. This was followed by PerMANOVA to compare the community composition among the two vertical heights and along the ridge, southern slope, and northern slope.

\section{Results}

\section{Longhorn beetle assemblage composition}

A total of 4090 individuals, 56 species, and 6 subfamilies of longhorn beetles were collected in the natural Mongolian oak forest. There were 2199 individuals belonging to 22 species of Cerambycinae, 1154 individuals belonging to 20 species of Lamiinae, 41 individuals belonging to 11 species of Lepturinae, only one species belonging to Aseminae, Prioninae, and Disteniinae, and 689 individuals belonging to Prioninae. Of the 56 species of longhorn beetles, only Massicus raddei (Blessig), Plagionotus pulcherpulcher (Blessig), Rhaphuma gracilipes (Faldermann), Mesosa myopsmyops (Dalman), Moechotypa diphysis (Pascoe), and Prionus insularis Motschulsky accounted for more than $1 \%$ of the total. There were 43 species and 2119 individuals in the canopy $(H)$ and 40 species and 1914 individuals in the bottom $(\mathrm{L})$. There were 39 species and 1782 individuals on the ridge (A), 34 species and 1370 individuals on the southern slope (B), and 29 species and 938 individuals on the northern slope (C) (Table $3)$.

\section{Table 3 Longhorn beetles assemblage composition}


Subfamilies/Species

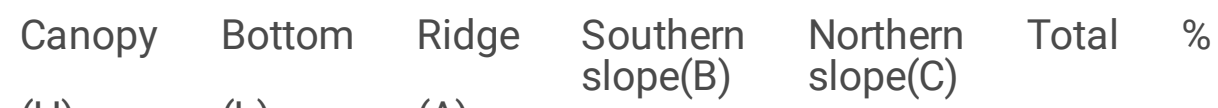
(H)
(L)
(A)

\section{Cerambycinae}

\begin{tabular}{|c|c|c|c|c|c|c|c|}
\hline $\begin{array}{l}\text { Amarysius } \\
\text { sanguinipennis (Blessig) }\end{array}$ & 1 & 0 & 0 & 0 & 1 & 1 & 0.02 \\
\hline $\begin{array}{l}\text { Anaglyptus } \\
\text { colobotbeoides (Bates) }\end{array}$ & 9 & 4 & 1 & 7 & 5 & 13 & 0.33 \\
\hline $\begin{array}{l}\text { Chlorophorus } \\
\text { motschulskyi (Ganglbauer) }\end{array}$ & 1 & 0 & 0 & 1 & 0 & 1 & 0.02 \\
\hline $\begin{array}{l}\text { Chlorophorus } \\
\text { sexmaculatus (Motschulsky) }\end{array}$ & 1 & 0 & 0 & 0 & 1 & 1 & 0.02 \\
\hline Chlorophorus sulcaticeps Pic & 2 & 2 & 2 & 2 & 0 & 4 & 0.10 \\
\hline $\begin{array}{l}\text { Chlorophorus } \\
\text { tohokensis Hayash }\end{array}$ & 1 & 0 & 0 & 1 & 0 & 1 & 0.02 \\
\hline $\begin{array}{l}\text { Cyrtoclytus } \\
\text { capracapra (Germar) }\end{array}$ & 8 & 18 & 7 & 10 & 9 & 26 & 0.65 \\
\hline Massicus raddei (Blessig) & 990 & 643 & 785 & 549 & 299 & 1633 & 39.93 \\
\hline Obrium obscuripenne Pic & 0 & 1 & 0 & 0 & 1 & 1 & 0.02 \\
\hline $\begin{array}{l}\text { Oupyrrhidium cinnabarium } \\
\text { cinnabarium (Blessig) }\end{array}$ & 0 & 1 & 0 & 1 & 0 & 1 & 0.02 \\
\hline $\begin{array}{l}\text { Plagionotus pulcherpulcher } \\
\text { (Blessig) }\end{array}$ & 154 & 91 & 106 & 105 & 34 & 245 & 5.99 \\
\hline
\end{tabular}

\begin{tabular}{|c|c|c|c|c|c|c|c|}
\hline $\begin{array}{l}\text { Purpuricenus } \\
\text { sideriger Fairmaire }\end{array}$ & 1 & 0 & 1 & 0 & 0 & 1 & 0.02 \\
\hline Rhaphuma acutivittis (Kraatz) & 1 & 3 & 2 & 0 & 2 & 4 & 0.10 \\
\hline $\begin{array}{l}\text { Rhaphuma } \\
\text { gracilipes (Faldermann) }\end{array}$ & 85 & 103 & 52 & 77 & 59 & 188 & 4.60 \\
\hline $\begin{array}{l}\text { Rhopalopus } \\
\text { speciosus Plavilstshikov }\end{array}$ & 1 & 0 & 1 & 0 & 0 & 1 & 0.02 \\
\hline $\begin{array}{l}\text { Trichoferus campestris } \\
\text { (Faldermann) }\end{array}$ & 7 & 4 & 2 & 8 & 1 & 11 & 0.28 \\
\hline Trichoferus guerryi (Pic) & 5 & 1 & 2 & 4 & 0 & 6 & 0.15 \\
\hline Xylotrechus clarinus Bates & 4 & 3 & 3 & 0 & 4 & 7 & 0.18 \\
\hline $\begin{array}{l}\text { Xylotrechus cuneipennis } \\
\text { cuneipennis (Kraatz) }\end{array}$ & 27 & 13 & 11 & 13 & 16 & 40 & 0.98 \\
\hline
\end{tabular}

Xylotrechus pyrrhoderus

$0 \quad 2$

$2 \quad 2$

0

2

0.05

Bates 


$\begin{array}{llllllll}\text { Xylotrechus rufilius Bates } & 8 & 3 & 3 & 6 & 2 & 11 & 0.28 \\ \begin{array}{l}\text { Chloridolum sieversi } \\ \text { (Ganglbauer) }\end{array} & 1 & 0 & 1 & 0 & 0 & 1 & 0.02\end{array}$

\section{Lamiinae}

\begin{tabular}{|c|c|c|c|c|c|c|c|}
\hline Acalolepta fraudatrix (Bates) & 0 & 1 & 0 & 0 & 1 & 1 & 0.02 \\
\hline $\begin{array}{l}\text { Acanthocinus } \\
\text { griseus (Fabricius) }\end{array}$ & 1 & 0 & 1 & 0 & 0 & 1 & 0.02 \\
\hline $\begin{array}{l}\text { Anoplophora } \\
\text { glabripennis Breuning }\end{array}$ & 0 & 1 & 0 & 1 & 0 & 1 & 0.02 \\
\hline $\begin{array}{l}\text { Eumecocera } \\
\text { impustulata (Motschulsky) }\end{array}$ & 1 & 3 & 2 & 1 & 1 & 4 & 0.10 \\
\hline $\begin{array}{l}\text { Eutetrapha } \\
\text { metallescens (Motschulsky) }\end{array}$ & 0 & 5 & 4 & 0 & 1 & 5 & 0.12 \\
\hline Exocentrus fisheri Gressitt & 6 & 0 & 1 & 4 & 1 & 6 & 0.15 \\
\hline Lamiomimus gottschei Kolbe & 3 & 10 & 7 & 6 & 0 & 13 & 0.33 \\
\hline Leiopus stillatus (Bates) & 2 & 1 & 3 & 0 & 0 & 3 & 0.07 \\
\hline $\begin{array}{l}\text { Menesia } \\
\text { sulphuratasulphurata (Gebler) }\end{array}$ & 1 & 0 & 0 & 0 & 1 & 1 & 0.02 \\
\hline Mesosa hirsute Bates & 4 & 0 & 0 & 4 & 0 & 4 & 0.10 \\
\hline $\begin{array}{l}\text { Mesosa } \\
\text { myopsmyops (Dalman) }\end{array}$ & 264 & 110 & 135 & 173 & 66 & 374 & 9.14 \\
\hline $\begin{array}{l}\text { Moechotypa } \\
\text { diphysis (Pascoe) }\end{array}$ & 456 & 241 & 258 & 323 & 116 & 697 & 17.04 \\
\hline $\begin{array}{l}\text { Monochamus guttulatus } \\
\text { (Gressitt) }\end{array}$ & 5 & 1 & 5 & 0 & 1 & 6 & 0.15 \\
\hline $\begin{array}{l}\text { Neacanista tuberculipennis } \\
\text { Gressitt }\end{array}$ & 31 & 1 & 16 & 11 & 5 & 32 & 0.79 \\
\hline Oplosia suvorovi (Pic) & 1 & 0 & 0 & 0 & 1 & 1 & 0.02 \\
\hline Pterolophia angusta (Bates) & 1 & 0 & 0 & 1 & 0 & 1 & 0.02 \\
\hline Pterolophia rigida (Bates) & 0 & 1 & 1 & 0 & 0 & 1 & 0.02 \\
\hline $\begin{array}{l}\text { Rhopa loscelisunifasciatus } \\
\text { Blessig }\end{array}$ & 0 & 1 & 1 & 0 & 0 & 1 & 0.02 \\
\hline Ropica dorsalis Schwarzer & 1 & 0 & 1 & 0 & 0 & 1 & 0.02 \\
\hline $\begin{array}{l}\text { Egesina bifasciana } \\
\text { Matsushita }\end{array}$ & 1 & 0 & 0 & 1 & 0 & 1 & 0.02 \\
\hline
\end{tabular}

\section{Lepturinae}




\begin{tabular}{|c|c|c|c|c|c|c|c|}
\hline $\begin{array}{l}\text { Anastrangalia sequensi } \\
\text { (Reitter) }\end{array}$ & 2 & 8 & 7 & 3 & 0 & 10 & 0.24 \\
\hline Anoplodera cyanea (Gebler) & 3 & 2 & 4 & 0 & 1 & 5 & 0.12 \\
\hline Gaurotes ussuriensis Blessig & 1 & 2 & 1 & 2 & 0 & 3 & 0.07 \\
\hline Leptura arcuata Panzer & 2 & 7 & 3 & 2 & 4 & 9 & 0.23 \\
\hline $\begin{array}{l}\text { Macroleptura thoracica } \\
\text { (Creutzer) }\end{array}$ & 1 & 3 & 1 & 2 & 1 & 4 & 0.10 \\
\hline Macropidonia ruficollis (Pic) & 0 & 1 & 0 & 1 & 0 & 1 & 0.02 \\
\hline $\begin{array}{l}\text { Pedostrangalia femoralis } \\
\text { (Motschulsky) }\end{array}$ & 2 & 0 & 1 & 1 & 0 & 2 & 0.05 \\
\hline Pidonia gibbicollis (Blessig) & 2 & 2 & 0 & 2 & 2 & 4 & 0.10 \\
\hline $\begin{array}{l}\text { Rhagium inquisitor } \\
\text { japonicum (Bates) }\end{array}$ & 0 & 1 & 0 & 1 & 0 & 1 & 0.02 \\
\hline $\begin{array}{l}\text { Stictoleptura } \\
\text { succedanea (Lewis) }\end{array}$ & 0 & 1 & 0 & 1 & 0 & 1 & 0.02 \\
\hline $\begin{array}{l}\text { Stictoleptura variicomis } \\
\text { (Dalman) }\end{array}$ & 0 & 1 & 1 & 0 & 0 & 1 & 0.02 \\
\hline
\end{tabular}

\section{Aseminae}

Arhopalus rusticus (Linnaeus) 0

2

$2 \quad 0$

$0 \quad 2 \quad 0.05$

Prioninae

$\begin{array}{llllllll}\text { Prionus insularis Motschulsky } & 75 & 614 & 344 & 44 & 301 & 689 & 16.85\end{array}$

\section{Disteniinae}

$\begin{array}{llllllll}\text { Distenia gracilis (Blessig) } & 3 & 2 & 2 & 2 & 1 & 5 & 0.12 \\ \text { Total } & 2176 & 1914 & 1782 & 1370 & 938 & 4090 & 100\end{array}$

Among the 56 species, 16 species were distributed only in the canopy $(H), 13$ species were distributed only in the bottom (L), and 27 species were distributed in both positions, as shown in Figure 1a. Among the 17 species distributed on the ridge, the southern slope, and the northern slope, 11 species were distributed only on the ridge, 10 species were distributed only on the southern slope, and 6 species were distributed only on the northern slope, as shown in Figure 1b.

\section{Species-abundance distribution with different vertical heights and slope directions}

When the number of traps was low, there was no significant difference in the number of species between the canopy and the bottom. When the number of traps exceeded 10 , the number of species in the canopy $(\mathrm{H})$ was higher than that in the bottom $(\mathrm{L})$. Under different topographic conditions, longhorn beetles 
collected by the same number of traps had higher number of species on the ridge (A), followed by the southern slope (B) and the northern slope $(C)$, as shown in Figure $2(a, b)$.

\section{The richness and abundance in the canopy and bottom}

Two-factor ANOVA was carried out for species number and individual number of longhorn beetles between topographic conditions $(A, B, C)$ and vertical heights $(H, L)$. The results showed that the interaction between topographic conditions and vertical height had no significant influence on the richness and abundance of the longhorn beetles, but the topographic conditions had a significant influence on the richness and abundance, while vertical height had a significant influence on the number of species (Table 4).

\section{Table 4 Repeated-measures MANOVA for topographic conditions and vertical height, and the interactive effects of number of species and number of individuals}

\begin{tabular}{llllll} 
Factors & d.f. & \multicolumn{2}{l}{ Individuals (N) } & \multicolumn{2}{l}{ Species (S) } \\
\cline { 3 - 6 } & & F & $P$ & F & $P$ \\
\hline HL & 1,94 & 0.46 & 0.499 & 5.069 & $\mathbf{0 . 0 2 7 *}$ \\
\hline ABC & 2,45 & 4.486 & $\mathbf{0 . 0 1 4 *}$ & 3.962 & $\mathbf{0 . 0 2 2 *}$ \\
\hline HLXABC & 2,45 & 0.865 & 0.424 & 0.246 & 0.782
\end{tabular}

With respect to the spatial vertical distribution, the richness and abundance of longhorn beetles in the canopy $(\mathrm{H})$ were significantly higher than those in the canopy $(\mathrm{L})\left(Q_{1,94}=6.737 ; p=0.009 ; Q_{1,94}=7.681 ; p\right.$ $=0.006$ ). Among all the subfamilies, the numbers of species and individuals of Cerambycinae were the highest, and the richness and abundance in the canopy $(\mathrm{H})$ were significantly higher than those in the bottom (L) $\left(Q_{1,94}=11.308 ; p=0.001 ; Q_{1,94}=8.696 ; p=0.003\right)$. The numbers of species and individuals of Lamiinae were the highest, and the richness and abundance in the canopy $(\mathrm{H})$ were significantly higher than those in the bottom (L) $\left(Q_{1,94}=11.765 ; p=0.01 ; Q_{1,94}=16.200 ; p=0.000\right)$. There was no significant difference in the richness and abundance of Lepturinae in the canopy $(H)$ and the bottom $(L)\left(Q_{1,94}=1.800\right.$; $p=0.180 ; Q_{1,94}=1.800 ; p=0.180$ ) (Figure 3).

\section{The richness and abundance of longhorn beetles on the ridge, southern slope, and northern slope}

The richness of longhorn beetles on the ridge $(A)$ and southern slope $(B)$ was significantly higher than that on the northern slope $(\mathrm{C})\left(Q_{2,93}=9.453, p=0.009\right)$, and the abundance on the ridge $(\mathrm{A})$ was significantly higher than that on the northern slope $(C)\left(Q_{2,93}=12.438, p=0.002\right)$ (Figure 2a). Among the major subfamilies, there was no significant difference in the richness of Cerambycinae on the ridge $(A)$, southern slope (B), and northern slope (C) $\left(Q_{2,93}=1.528, p=0.446\right)$, but the abundance was significantly higher on the ridge (A) and southern slope (B) than on the northern slope (C) $\left(Q_{2,93}=9.276, p=0.01\right)$ (Figure $\left.2 \mathrm{~b}\right)$. The richness and abundance of Lamiinae on the ridge $(A)$ and southern slope $(B)$ were significantly higher than those on the northern slope (C) $\left(Q_{2,93}=14.000, p=0.001 ; Q_{2,93}=6.397, p=0.041\right)$ (Figure 2c). The richness 
and abundance of Lepturinae were not significantly different among the ridge (A), southern slope (B), and northern slope (C) $\left(Q_{2,93}=1.104, p=0.576 ; Q_{2,93}=1.114, p=0.564\right)$ (Figure $2 \mathrm{~d}$ ).

\section{Indicator species}

With respect to vertical height, three longhorn beetles were significantly associated with traps placed in the canopy $(H)$, and one species was significantly associated with the bottom $(L)$. Among the three directions, Massicus raddei (Blessig) was significantly associated with the ridge (A), and Mesosa myopsmyops (Dalman) was significantly associated with the ridge and the southern slope (B). On the ridge (A), Mesosa myopsmyops (Dalman), Moechotypa diphysis (Pascoe), and Neacanista tuberculipennis Gressitt were significantly associated with the ridge canopy (AH), and Prionus insularis Motschulsky and Lamiomimus gottschei Kolbe were significantly associated with the ridge bottom (AL). On the southern slope (B), Mesosa myopsmyops (Dalman) and Neacanista tuberculipennis Gressitt were significantly associated with the southern canopy (BH), and Prionus insularis Motschulsky was significantly associated with the southern bottom (BL). Only Mesosa myopsmyops (Dalman) was significantly associated with the northern canopy $(\mathrm{CH})$ on the northern slope (Table 5).

Table 5 Significant trap height associations based on indicator species analysis 


\begin{tabular}{|c|c|c|c|c|c|}
\hline $\begin{array}{l}\text { Location } \\
\text { combination }\end{array}$ & $\begin{array}{l}\text { Spatial } \\
\text { position }\end{array}$ & Species & IV & $p$ & $\begin{array}{l}\text { Number of } \\
\text { individuals }\end{array}$ \\
\hline \multirow[t]{4}{*}{$\mathrm{H} \times \mathrm{L}$} & $\mathrm{H}$ & $\begin{array}{l}\text { Mesosa } \\
\text { myopsmyops (Dalman) }\end{array}$ & 66.2 & 0.0001 & 374 \\
\hline & $\mathrm{H}$ & $\begin{array}{l}\text { Neacanista tuberculipennis } \\
\text { Gressitt }\end{array}$ & 32.3 & 0.0001 & 32 \\
\hline & $\mathrm{H}$ & $\begin{array}{l}\text { Plagionotus } \\
\text { pulcherpulcher (Blessig) }\end{array}$ & 48.5 & 0.0187 & 245 \\
\hline & L & $\begin{array}{l}\text { Prionus insularis } \\
\text { Motschulsky }\end{array}$ & 70.5 & 0.0002 & 689 \\
\hline \multirow[t]{2}{*}{$A \times B \times C$} & A & Massicus raddei (Blessig) & 48.1 & 0.0038 & 1633 \\
\hline & B & $\begin{array}{l}\text { Mesosa } \\
\text { myopsmyops (Dalman) }\end{array}$ & 41.9 & 0.0265 & 374 \\
\hline \multirow[t]{5}{*}{ A } & $\mathrm{AH}$ & $\begin{array}{l}\text { Mesosa } \\
\text { myopsmyops (Dalman) }\end{array}$ & 75.6 & 0.0002 & 374 \\
\hline & $\mathrm{AH}$ & $\begin{array}{l}\text { Moechotypa } \\
\text { diphysis (Pascoe) }\end{array}$ & 77.5 & 0.0152 & 697 \\
\hline & $\mathrm{AH}$ & $\begin{array}{l}\text { Neacanista tuberculipennis } \\
\text { Gressitt }\end{array}$ & 41.0 & 0.0170 & 32 \\
\hline & AL & $\begin{array}{l}\text { Prionus insularis } \\
\text { Motschulsky }\end{array}$ & 76.3 & 0.0068 & 689 \\
\hline & AL & Lamiomimus gottschei Kolbe & 37.5 & 0.0184 & 13 \\
\hline \multirow[t]{3}{*}{ B } & $\mathrm{BH}$ & $\begin{array}{l}\text { Mesosa } \\
\text { myopsmyops (Dalman) }\end{array}$ & 66.5 & 0.0398 & 374 \\
\hline & $\mathrm{BH}$ & $\begin{array}{l}\text { Neacanista tuberculipennis } \\
\text { Gressitt }\end{array}$ & 37.5 & 0.0193 & 32 \\
\hline & $B L$ & $\begin{array}{l}\text { Prionus insularis } \\
\text { Motschulsky }\end{array}$ & 55.4 & 0.0497 & 689 \\
\hline C & $\mathrm{CH}$ & $\begin{array}{l}\text { Mesosa } \\
\text { myopsmyops (Dalman) }\end{array}$ & 57.9 & 0.0485 & 374 \\
\hline
\end{tabular}

\section{Community composition}

Non-metric multidimensional scaling yielded a two-dimensional solution with a final stress of 22.88 . The $R^{2}$ values were 0.45 (axis 1 ) and 0.31 (axis 2). It was clear from the two-dimensional depiction of these results (based on axes 1 and 2 ) that the longhorn beetle assemblage sampled in the canopy $(H)$ was compositionally distinct from that sampled at the bottom $(\mathrm{L})$, and the beetle assemblage in the canopy $(\mathrm{H})$ and at the bottom $(L)$ of the three positions $(A, B, C)$ differed (Figure 5 ).

The PerMANOVA results indicated that the longhorn beetle assemblage sampled in the canopy $(H)$ was compositionally distinct from that at the lower level $(L)(t=2.54, p=0.0018)$. There was a significant 
difference in the assemblage composition on the three positions $(t=2.47, p=0.0014)$; the ridge (A) was compositionally distinct from the southern slope $B(t=1.810, p=0.003)$ and the northern slope (C) $(t=$ $1.723, p=0.004)$. There was a significant difference between the assemblage composition of traps placed in the ridge canopy $(\mathrm{AH})$ and on the southern slope canopy $(\mathrm{BH})(t=1.902, p=0.003)$, and on the southern slope canopy $(\mathrm{BH})$ and on the northern slope canopy $(\mathrm{CH})(t=1.426, p=0.048)$. Only on the ridge $(\mathrm{A})$, beetle assemblages composition were different on the canopy (AH) from those on the bottom (AL) $(t=$ 2.157, $p=0.0006)$ (Table 6).

Table 6 The PerMANOVA results of the beetle assemblage sampled at different positions

\begin{tabular}{llll} 
Sampling position & $d f$ & $t$ & $p$ \\
\hline HL & $\mathbf{1 , 9 4}$ & $\mathbf{3 . 5 3 8}$ & $\mathbf{0 . 0 0 1 8 ^ { * }}$ \\
\hline ABC & $\mathbf{2 , 9 3}$ & $\mathbf{2 . 4 6 8}$ & $\mathbf{0 . 0 0 1 4 ^ { * }}$ \\
\hline A-B & & $\mathbf{1 . 8 1 0}$ & $\mathbf{0 . 0 0 3 ^ { * }}$ \\
\hline B-C & & 0.937 & 0.516 \\
\hline A-C & & $\mathbf{1 . 7 2 3}$ & $\mathbf{0 . 0 0 4 ^ { * }}$ \\
\hline ABCHL & $\mathbf{5 , 9 0}$ & $\mathbf{2 . 1 7 3}$ & $\mathbf{0 . 0 0 1 ^ { * }}$ \\
\hline AH-BH & & $\mathbf{1 . 9 0 2}$ & $\mathbf{0 . 0 0 3 ^ { * }}$ \\
\hline AH-CH & & 0.911 & 0.531 \\
\hline BH-CH & & $\mathbf{1 . 4 2 6}$ & $\mathbf{0 . 0 4 8 ^ { * }}$ \\
\hline AL-BL & & 1.031 & 0.378 \\
\hline AL-CL & & 0.938 & 0.836 \\
\hline BL-CL & & 1.291 & 0.091 \\
\hline AH-AL & & $\mathbf{2 . 1 5 7}$ & $\mathbf{0 . 0 0 0 6}$ \\
\hline BH-BL & & 0.906 & 0.602 \\
\hline CH-CL & & 1.178 & 0.203
\end{tabular}

\section{Correspondence analysis of longhorn beetles and different positions}

The individual number of 56 species of longhorn beetles from 6 subfamilies was square root transformed. Correspondence analysis was conducted between the canopy $(H)$ and bottom $(L)$ and the ridge $(A)$, southern slope (B), and northern slope (C) for 6 subfamilies and 56 species of longhorn beetles, and the results are shown in Figure $6(a, b)$. In Figure $6(a)$, the contribution rate of the first axis was $60.07 \%$, and that of the second axis was $39.93 \%$. The cumulative contribution rate was $100 \%$, and the eigenvalue $=$ 0.18. In Figure 6 (b), the contribution rate of the first axis was $39.08 \%$, and that of the second axis was $17.36 \%$. The cumulative contribution rate was $56.44 \%$, and the eigenvalue $=0.36$. 
Among the six subfamilies, Lamiinae ( $n 1)$, Lepturinae ( $n 2)$, Disteniinae ( $n 4)$, and Cerambycinae $(n 5)$ had a strong correlation with the slope direction of the ridge (A) and southern slope (B). Prioninae (n3) had a strong correlation with the ridge (A) and northern slope (C), while Aseminae (n6) had only one species collected from the ridge (A). In the bottom and canopy under different topographic conditions, only one species of Aseminae (N6) was collected from the bottom of the ridge (A), and only one species of Prioninae (N3) was closely related to the ridge bottom (AL) and northern slope bottom (CL). Lepturinae $(n 2)$ was closely related to the ridge bottom (AL), while Lamiinae $(n 1)$ and Cerambycinae $(n 5)$ were closely related to the ridge canopy $(\mathrm{AH})$, southern slope canopy $(\mathrm{BH})$, and northern slope $(\mathrm{CH})$.

The majority of the 56 species of longhorn beetles were closely related to the ridge canopy (AH), southern slope canopy $(\mathrm{BH})$, and northern slope $(\mathrm{CH})$. Among the species with more individuals, Mesosa myopsmyops (Dalman) (11), Moechotypa diphysis (Pascoe) (12), Massicus raddei (Blessig) (41), and Plagionotus pulcherpulcher (Blessig) (44) were closely related to the ridge canopy (AH), southern slope canopy (BH), and northern slope (CH), while Rhaphuma gracilipes (Faldermann) (47) was closely related to the southern slope bottom (BL) and northern slope bottom (CL). Prionus insularis Motschulsky (32) was closely related to the ridge bottom $(\mathrm{AL})$ and northern slope bottom $(\mathrm{CL})$.

\section{Discussion}

\section{Longhorn beetle community composition}

In this study, 96 traps were used to continuously collect longhorn beetle specimens during the whole active period, and a large number of individuals were collected, totaling 4090, which exceeded the number of longhorn beetles collected in a broad-leaved Korean pine forest by Liu et al. (1525) and Li et al. (1303) (Liu et al. 2015; Li et al. 2016). Although no lure was used in the whole collection process, the number of species and individuals collected was relatively high, which indicated that the collection efficiency of longhorn beetles can be improved by setting traps in the canopy and the bottom simultaneously.

The stand composition is a comprehensive reflection of the forest succession process. In a forest with high spatial heterogeneity, more species requiring special habitats can survive (Buongiorno 1994; Uuttera et al. 1996). The composition and diversity of stands affected the diversity and richness of longhorn beetles, and the richness of longhorn beetles in this study was lower than that in a broad-leaved Korean pine forest (Liu et al. 2015; Li et al. 2016). This was related to the relatively simple composition and structure of the Mongolian oak forest (Huang and Zhou 2003; Yang et al. 2015).

Among the 56 species of longhorn beetles, there were 50 species with individuals accounting for less than $1 \%$ of the total, accounting for $89.29 \%$ of the total species, which is consistent with the research of Hanks et al., in which the species with fewer individuals accounted for the majority (Hanks et al. 2012, 2013, 2014; Liu et al. 2015). Massicus raddei (Blessig), Moechotypa diphysis (Pascoe), Prionus insularis Motschulsky, Mesosa myopsmyops (Dalman), and Plagionotus pulcherpulcher (Blessig) were highly abundant, which are important saproxylic beetles and mainly feed on the decaying, dying, or dead wood of Mongolian oak. In particular, Massicus raddei (Blessig), which accounted for $39.93 \%$ of the total quantity, 
has caused serious damage in the study area, and much of the larger-diameter Quercus mongolica has been invaded by Massicus raddei (Blessig). In this study, the species richness of Cerambycinae, Lamiinae, and Lepturinae was high, but the abundance of Lepturinae was low, which was related to the simple stand composition and few flowering plants in the oak forest (Gao et al. 2005).

\section{Spatial distribution of the longhorn beetle community}

Most longhorn beetles are herbivorous insects, and their diversity and richness are closely related to the diversity of plants (Wang et al. 2005; Noguera et al. 2017). In natural forests, the tree composition is a comprehensive reflection of the forest succession process. Topographic factors, such as slope aspect, affect the distribution pattern of longhorn beetles by influencing the composition and diversity of trees, light, temperature, humidity, and other microenvironments in the habitat (Peris-Felipo et al. 2011). In this study, topography and vertical height affected the distribution pattern of the richness, abundance, and community composition of longhorn beetles, but there was no interaction between topography and vertical distribution. The community composition of longhorn beetles on the ridge was significantly different from that on the southern slope and the northern slope. The richness and abundance of longhorn beetles were higher on the ridge and southern slope, which was related to the better light conditions on the ridge and southern slope and the larger $\mathrm{DBH}$ of the trees. The richness and abundance of longhorn beetles were higher in the stands with trees with a greater diameter (Haavik and Stephen 2010; Liu et al. 2015). This distribution pattern of longhorn beetles is also related to the fact that different plants at different locations in the forest can release different volatiles and attract different species of longhorn beetles (Dodds et al. 2010).

The spatial distribution pattern of insects in the forest is also the result of long-term adaptation of species to the environment (Matheron 1967; Graham et al. 2012). Light has an obvious effect on the activity of longhorn beetles. Many longhorn species are phototropic or prefer to move in the environment with sufficient light (Ji et al. 1991). In this study, the vertical distribution of longhorn beetles was not affected by topographic factors in the Mongolian oak forest, and the community composition of longhorn beetles was significantly different in the bottom and canopy of the oak forest, which is consistent with the results of Ulyshen's study (Ulyshen and Sheehan 2019). The richness and abundance of longhorn beetles in the forest canopy were higher than those at the bottom; the number in the canopy accounted for $76.79 \%$ of the total. This is mainly because the light and temperature of the canopy were more variable than those of the bottom, which can provide different community structures and environmental conditions from those of the bottom, and some dead branches in the canopy can provide an ideal habitat for some wood-eating longhorn beetles to feed and lay eggs, which can result in the survival of more beetles (Weiss et al. 2016, 2019; Ramos-Robles et al. 2020; Miller et al. 2020). A total of 11 species were collected only in the canopy, which is consistent with the distribution of some longhorn beetles only in the canopy (Engelken and Mccullough 2020). A total of 27 longhorn beetle species were distributed in both the canopy and the bottom, which is consistent with the study by Miller et al. in which most species were distributed at the bottom and in the canopy of the forest (Miller et al. 2020). 
The species and subfamilies with different habits showed different distribution patterns in the canopy and bottom (Ulyshen et al. 2019), and different species were distributed in different parts of the forest (Li et al. 2017; Flaherty et al. 2019; Foit et al. 2019). In this study, Massicus raddei (Blessig), Moechotypa diphysis (Pascoe), and Mesosa myopsmyops (Dalman) preferred to be active in the canopy. The results for some indicator species support this view, which is related to the vertical distribution of larvae in the trunk (Yang et al. 2012). The richness and abundance of Cerambycinae and Lamiinae were higher in the canopy, and the indicator species of these subfamilies in the canopy also supported this view, which is similar to the distribution of these groups in previous studies (Rassati et al. 2019; Engelken and Mccullough 2020).

Although the canopy plays an important role in protecting the diversity of longhorn beetles, the bottom is also an important habitat for longhorn beetles, and some longhorn beetles have higher richness in the bottom of the forest (Vance et al. 2003). Some wood-eating longhorn beetle larvae prefer to live in specific locations in the trunk, while some species decrease with the height of the trunk, which is related to the habitat conditions such as different bark thicknesses that these locations can provide for longhorn beetles (Cadorette-Breton et al. 2016). In this study, Prionus insularis Motschulsky preferred to move at the bottom, and the emergence holes were more distributed on trunks with larger DBH near some bottom traps, and the spatial distribution showed a state of aggregation, indicating that the health status and DBH of trees affect the choice of a host of longhorn beetles (Li et al. 2016, 2018; Chen et al. 2018). Some studies have shown that the number of Lepturinae with the habit of visiting flowers is higher at the bottom (Rassati et al. 2019), but the same result was not found in this study, which may be due to the lack of flowering plants in the bottom layer of the Mongolian oak forest.

\section{Conclusion}

In the Mongolian oak forest of Changbai Mountain, the richness and abundance of longhorn beetles were significantly affected by topographic conditions. The richness and abundance of longhorn beetles were higher on the ridge and southern slope with higher light conditions, and the community composition on the ridges was significantly different from that on other slopes. There was a certain vertical distribution pattern of longhorn beetles in the forest, the species composition was different in the canopy and at the bottom, and the richness of longhorn beetles was higher in the canopy with better light conditions. The vertical distribution of different subfamilies differed in the stand. Cerambycinae and Lamiinae tended to be active in the canopy, and Prioninae tended to be active in the bottom of the stand. The topographic conditions and vertical height of the stand affect the richness, abundance, and community composition of longhorn beetles. Therefore, in the future monitoring of longhorn beetle populations, alien invasive species, and pests, it is necessary to fully consider the monitoring sites to cover as many diverse terrains and vertical positions as possible.

\section{Abbreviations}

DBH: Diameter at breast height; H: Canopy layer, L: Bottom layer, A; Ridge, B: Southern slope; C: northern slope; AH: Ridge canopy layer; AL: Ridge bottom layer; BH: Souther slope canopy layer; BL: Souther slope 
bottom layer; $\mathrm{CH}$ : Northern slope canopy layer; $\mathrm{CL}$ : Northern slope bottom layer.

\section{Declarations}

\section{Acknowledgments}

We would like to thank Prof. Gao Wentao (Beihua University) for helping to identify longhorn beetles specimens.

\section{Authors' contributions}

Shengdong Liu, Qingfan Meng and Yinghua Jin designed this research. Shengdong Liu, Xin Meng, Qingfan Meng, Yan Li and Hongri Zhao carried out the fieldwork and made specimens. Shengdong Liu analyzed the results, and wrote the paper. Yinghua Jin facilitated in the data analysis. The author(s) read and approved the final manuscript.

\section{Funding}

This research was supported by grants from the National Natural Science Foundation of China (31600517), the Science and Technology Development Project of Jilin Province (20180201059NY), Open Project of Key Laboratory of Geographical Processes and Ecological Security of Changbai Mountains, Ministry of Education (GPES202003).

\section{Availability of data and materials}

The data are available upon a reasonable request to the Authors.

\section{Ethics approval and consent to participate}

Not applicable.

\section{Consent for publication}

Not applicable.

\section{Competing interests}

The authors declare that they have no competing interests.

\section{Author details}

1 Jilin Provincial Key Laboratory of Insect Biodiversity and Ecosystem Function of Changbai Mountains, Beihua University, Jilin 132013, China;

${ }^{2}$ College of Forestry, Beijing Forestry University, Beijing 100083, China. 
${ }^{3}$ Key Laboratory of Geographical Processes and Ecological Security of Changbai Mountains, Ministry of Education; School of Geographical Sciences, Northeast Normal University, Changchun 130024, China.

Correspondence: qingfanmeng@163.com

\section{References}

1. Alexander KNA (2008) Tree biology and saproxylic Coleoptera: issues of definitions and conservation language. Rev Écol -Terre Vie 63:9-13

2. Boucher J, Azeria ET, Ibarzabal J, Hébert C (2012) Saproxylic beetles in disturbed boreal forests: temporal dynamics, habitat associations, and community Structure. Ecoscience 19(4):328-343. http://doi.org/10.2980/19-4-3503

3. Boulanger Y, Sirois L, Hébert C (2013) Distribution Patterns of Three Long-Horned Beetles (Coleoptera: Cerambycidae) Shortly After Fire in Boreal Forest: Adults Colonizing Stands Versus Progeny Emerging From Trees. Environ Entomol 42(1):17-28. http://doi.org/10.1603/EN12003

4. Buongiorno J, Dahir S, Lu H, Lin CR (1994) Tree size diversity and economic returns in uneven-aged forest stand. Forest Science 40(1):83-103

5. Buse J, Ranius T, Assmann T (2008) An endangered longhorn beetles beetle associated with old oaks and its possible role as an ecosystem engineer. Conserv Biol 22:329-337. http://doi.org/10.1111/j.1523-1739.2007.00880.x

6. Cadorette-Breton Y, Hébert C, Ibarzabal J, Berthiaume R, Bauce É (2016) Vertical distribution of three longhorn beetlesed beetle species (Coleoptera: Cerambycidae) in burned trees of the boreal forest. Can J For Res 46(4):564-571. http://doi.org/10.1139/cjfr-2015-0402

7. Casula P, Fantini S, Fenu G, Fois M, Calvia G, Bacchetta G (2021) Positive interactions between great longhorn beetles and forest structure. For Ecol Manage 486:118981. http://doi.org/10.1016/j.foreco.2021.118981

8. Chen Q, Xu ZC, Zhang LS, Lu PF, Zhang YF (2018) Geostatistical analysis of the spatial distribution of Arhopalus rusticus larvae and adults. Acta Ecol Sin 38(3):975-983. http://doi.org/10.5846/stxb201611182350 (in Chinese .

9. Colwell RK (2013) Estimate S: Statistical estimation of species richness and shared species from samples. http://viceroy.eeb.uconn.edu/estimates

10. Dodds KJ, Dubois GD, Hoebeke ER (2010) Trap Type, Lure Placement, and Habitat Effects on Cerambycidae and Scolytinae (Coleoptera) Catches in the Northeastern United States. J Econ Entomol 103(3):698-707. http://doi.org/10.1603/EC09395

11. Eliott M, Lawson S, Hayes A, Debuse V, York A, Lewis T (2019) The response of cerambycid beetles (Coleoptera: Cerambycidae) to long-term fire frequency regimes in subtropical eucalypt forest. Austral Ecol 44:609-620. http://doi.org/10.1111/aec.12702

12. Engelken PJ, Mccullough DG (2020) Species Diversity and Assemblages of Cerambycidae in the Aftermath of the Emerald Ash Borer (Coleoptera: Buptrestidae) Invasion in Riparian Forests of 
Southern Michigan. Environ Entomol 49(2):391-404. http://doi.org/10.1093/ee/nvaa013

13. Flaherty L, Gutowski JMG, Mayo P, Mokrzycki T, Pohl G, Silk P, Van K, Sweeney JD (2019)

Pheromoneenhanced lure blends and multiple trap heights improve detection of bark and woodboring beetles potentially moved in solid wood packaging. J Pest Sci 92:309-325.

http://doi.org/10.1007/s10340-018-1019-4

14. Foit J, Čermák V, Gaar V, Hradil K, Nový V, Rolincová P (2019) New insights into the life history of Monochamus galloprovincialis can enhance surveillance strategies for the pinewood nematode. J Pest Sci 92:1203-1215. http://doi.org/10.1007/s10340-019-01110-y

15. Gao WT, Chen YB, Meng QF (2014) ï» ¿Faunal Composition and Vertical Distribution Characteristics of Cerambycidae in Changbai Mountain Reserve. Scientia Silvae Sinicae 50(9):89-96 (in Chinese)

16. Gao WT, Meng QF, Zheng XB, Zhang YZ, Li Y (2005) Fauna of flower-visiting longicorn beetles in north slope of Changbai Mountain. Chinese Bulletin of entomology 42(6):691-694 (in Chinese)

17. Graham EE, Poland TM, McCullough DG, Millar JG (2012) A comparison of trap type and height for capturing cerambycid beetles (Coleoptera). J Econ Entomol 105:837-846. http://doi.org/10.1603/EC12053

18. Grove SJ (2014) The influence of forest management history on the integrity of the saproxylic beetle fauna in an Australian lowland tropical rainforest. Biol Cons 104:149-171.

http://doi.org/10.1016/S0006-3207(01)00140-9

19. Guo YL, Meng QF, Gao WT (2012) Visulization and pattern analysis of plant-insect pollinator interaction networks in subalpine meadow in Changbai Mountain. Scientia Silvae Sinicae 48(12):141-147 (in Chinese)

20. Haavik LJ, Stephen FM (2010) Stand and individual tree characteristics associated with Enaphalodes rufulus (Haldeman) (Coleoptera: Cerambycidae) infestations within the Ozark and Ouachita National Forests. For Ecol Manage 259(10):1938-1945. http://doi.org/10.1016/j.foreco.2010.02.005

21. Hammond HEJ, Langor DW, Spence JR (2017) Changes in saproxylic beetle (Insecta: Coleoptera) assemblages following wildfire and harvest in boreal Populus forests. For Ecol Manage 401:319-329. http://doi.org/10.1016/j.foreco.2017.07.013

22. Hanks LM, Millar JG (2013) Field bioassays of cerambycid pheromones reveal widespread parsimony of pheromone structures, enhancement by host plant volatiles, and antagonism by components from heterospecifics.Chemoecology 23:21-44. http://doi.org/10.1007/s00049-012-0116-8

23. Hanks LM, Millar JG, Mongold-Diers JA, Wong JCH, Mitchell RF (2012) Using blends of cerambycid beetle pheromones and host plant volatiles to simultaneously attract a diversity of cerambycid species. Canadian Journal Forest Research 42:1050-1059. http://doi.org/10.1139/x2012-062

24. Hanks LM, Reagel PF, Mitchell RF, Wong JCH, Meier LR, Silliman CA, Graham EE, Striman BL, Robinson KP, Mongold-Diers JA (2014) Seasonal phenology of the cerambycid beetles of east central Illinois. Ann Entomol Soc Am 107:211-218. http://doi.org/10.1603/AN13067

25. Huang JH, Zhou SY (2003) Study on cerambycidae (Coleoptera: Polyphaga) Diversity in maoershan, guangxi. Journal of Guangxi Normal University 21(3):82-86 (in Chinese) 
26. Ji BZ, Gong XY, Liu SW (1991) The relationship of ommatidium density and activity behavior rhythm and phototactic behavior of adult longicorn beetles. Forest Pest and Disease (2):15-17 (in Chinese)

27. Ji BZ, Wei Y, Huang ZY (2002) Present situations and prospects of researches on adult's behavior of longicorn beetles. Journal of Nanjing Forestry University (Natural Sciences Edition) 26(2):79-83 (in Chinese)

28. Jiang SN, Cheng L (2001) China fauna. Insects (21). Coleoptera. Cerambycidae. Science Press, Lepturinae.Beijing, pp 1-223 (in Chinese)

29. Karpiński L, Maák I, Wegierek $P$ (2021) The role of nature reserves in preserving saproxylic biodiversity: using longhorn beetles (Coleoptera: Cerambycidae) as bioindicators, The. European Zoological Journal 88(1):487-504. http://doi.org/10.1080/24750263.2021.1900427

30. Kato M, Inque T, Hamid AA, Nagamitsu T, Merdek MB, Nona AR, Itino T, Yamane S, Yumoto T (1995) Seasonality and vertical structure of light-attracted insect communities in a dipterocarp forest in Sarawak. Researches on Population Ecology 37:59-79. http://doi.org/10.1007/BF02515762

31. Lamarre GPA, Molto Q, Fine PVA, Baraloto C (2012) A comparison of two common flight interception traps to survey tropical arthropods. ZooKeys 216:43-55. http://doi.org/10.3897/zookeys.216.3332

32. Lassauce A, Larrieu L, Paillet $Y$, Bouget C (2013) The effects of forest age on saproxylic beetle biodiversity: implications of shortened and extendedrotation lengths in a French oak high forest. Insect Conservation Diversity 6:396-410. http://doi.org/10.1111/j.1752-4598.2012.00214.x

33. Lee CJ, Baxt A, Castillo S, Berkov A (2014) Stratification in French Guiana: Cerambycid beetles go up when rains come down. Biotropica 46(3):302-311. http://doi.org/10.1111/btp.12101

34. Li JQ, Mei ZX, Yang ZQ (2016) Geostatistical analysis on the spatial distribution of Batocera lineolata (Coleoptera: Cerambycidae) populations in different types of ash tree forests. Acta Ecol Sin 36(14):4540-4547 (in Chinese)

35. Li JQ, Mei ZX, Yang ZQ (2018) Geostatistical analysis on spatial distribution pattern of Batocera horsfieldi (Coleoptera: Cerambycidae) populations in different poplar forest types. Scientia Silvae Sinicae 54(3):83-90 (in Chinese)

36. Li LY, Meng QF, Li Y, Gao WT (2016) Efficacy of semiochemical lures for trapping of longhorn beetles (Coleoptera: Cerambycidae) in broad-leaved Korean pine forest. Journal of Nanjing Forestry University (Natural Sciences Edition) 40(4):113-118 (in Chinese)

37. Li LY, Meng QF, Li Y, Gao WT (2015) Relative efficiency of three trap types for monitoring longhorn beetles (Coleoptera: Cerambycidae). Chinese Journal of Applied Entomology 52(5):1305-1311 (in Chinese)

38. Li Y, Meng QF, Silk P, Gao WT, Mayo P, Sweeney J (2017) Effect of semiochemicals and trap height on catch of Neocerambyx raddei in Jilin province, China. Entomol Exp Appl 164:94-101. http://doi.org/10.1111/eea.12600

39. Linsley EG (1961) The Cerambycidae of North America. Part I. Introduction. Univ Calif Publ Entomol 18:1-135 
40. Liu SD, Gao WT, Li Y, Shi Y, Meng QF (2015) Comparative study of Cerambycidae species diversity in different forest stands of southern Zhangguangcai Mountains. Journal of Beijing Forestry University 37(5):110-118 (in Chinese)

41. Luo F, Meng LZ, Aluthwattha ST, Lin MY, Weigel A, Zhang WF, Qi JH, Chen J (2021) Scale-dependent contribution of host-specificity and environmental factors to wood-boring longhorn beetle community assemblage in SW China. Sci Rep 11:5100. http://doi.org/10.1038/s41598-021-84511-3

42. Matheron G (1967) Kriging, or polynomial interpolation procedures. Canadian Mining Metallurgical Bulletin 60:1041-1045

43. McCune B, Mefford MJ (2011) PC-ORD. Multivariate analysis of ecological data. Version 6. MjM Software, Gleneden Beach

44. McGeoch MA, Schroeder M, Ekbom B, Larsson S (2010) Saproxylic beetle diversity in a managed boreal forest: importance of stand characteristics and forestry conservation measures. Divers Distrib 13(4):418-429. http://doi.org/10.1111/j.1472-4642.2007.00350.x

45. Meng LZ, Martin K, Weigel A, Yang XD (2013) Tree Diversity Mediates the Distribution of Longhorn beetles (Coleoptera: Cerambycidae) in a Changing Tropical Landscape (Southern Yunnan, SW China). PLoS ONE 8(9):e75481. http://doi.org/10.1371/journal.pone.0075481

46. Miller DR, Crowe CM, Sweeney JD (2020) Trap height affects catches of bark and woodboring beetles (coleoptera: curculionidae, cerambycidae) in baited multiple-funnel traps in Southeastern United States. J Econ Entomol 113(1):273-280. http://doi.org/10.1093/jee/toz271

47. Noguera FA, Ortega-Huerta MA, Zaragoza-Caballero S, González-Soriano E, Ramírez-García E (2017) Species Richness and Abundance of Cerambycidae (Coleoptera) in Huatulco, Oaxaca, Mexico; Relationships with Phenological Changes in the Tropical Dry Forest. Neotropical Entomology 47:457469. http://doi.org/10.1007/s13744-017-0534-y

48. Noguera FA, Zaragoza-Caballero S, Chemsak JA, Alicia RP, Enrique R, Enrique GS, Ricardo A (2002) Diversity of the family Cerambycidae (Coleoptera) of the tropical dry forest of Mexico, I. Sierra de Huautla, Morelos. Ann Entomol Soc Am 95(5):617-627. https://doi.org/10.1603/00138746(2002)095[0617:DOTFCC]2.0.C0;2

49. Ohsawa M (2004) Species richness of Cerambycidae in larch plantations and natural broad-leaved forests of the central mountainous region of Japan. For Ecol Manage 189:375-385. https://doi.org/10.1016/j.foreco.2003.09.007

50. Peris-Felipo FJ, Falcó-Garí JV, Jiménez-Peydró R (2011) The diversity of cerambycidae in the protected mediterranean landscape of the Natural Park of Carrascal de La Font Roja, Spain. Bull Insectol 64(1):87-92

51. Ramos-Robles M, Vargas-Cardoso OR, Corona-López AM, Flores-Palacios A, ToledoHernández VH (2020) Spatio-temporal variation of Cerambycidae-host tree interaction networks. PLoS ONE 15(2):e0228880. https://doi.org/10.1371/journal.pone.0228880

52. Rassati D, Marchioro M, Flaherty L, Poloni R, Edwards S, Faccoli M, Sweeney JD (2020) Response of native and exotic longhorn beetles to common pheromone components provides partial support for 
the pheromone-free space hypothesis. Insect Sci 28(3):793-810. https://doi.org/10.1111/17447917.12790

53. Rassati D, Marini L, Marchioro M, Rapuzzi P, Magnani G, Poloni R, Giovanni FD, Mayo P, Sweeney JD (2019) Developing trapping protocols for wood-boring beetles associated with broadleaf trees. J Pest Sci 92:267-279. https://doi.org/10.1007/s10340-018-0984-y

54. Saint-Germain M, Buddle CM, Drapeau P (2006) Sampling saproxylic Coleoptera: scale issues and the importance of behavior. Environ Entomol 35(2):478-487. https://doi.org/10.1603/0046-225X35.2.478

55. Schmeelk TC, Millar JG, Hanks LM (2016) Influence of trap height and bait type on abundance and species diversity of cerambycid beetles captured in forests of east-central Illinois. J Econ Entomol 109:1750-1757. https://doi.org/10.1093/jee/tow102

56. Sirami C, Jay-Robert P, Brustel H, Valladares L, Guilloux SL, Martin JL (2008) Saproxylic beetle assemblages of old Holm-oak trees in the Mediterranean region: role of a keystone structure in a changing heterogeneous landscape. Rev Écol -Terre Vie 63:93-106

57. Solow AR, Roberts DL (2006) Museum collections, species distributions, and rarefaction. Divers Distrib 12(4):423-424. https://doi.org/10.1111/j.1366-9516.2006.00259.x

58. Speight MCD (1989) Saproxylic invertebrates and their conservation. Nature Environment 42:1-79

59. Su JC, Woods SA (2001) Importance of sampling along a vertical gradient to compare the insect fauna in managed forests. Environ Entomol 30:400-408. https://doi.org/10.1603/0046-225X30.2 .400

60. Sugimoto H, Togashi K (2013) Canopy-related adult density and sex-related flight activity of Monochamus alternatus (Coleoptera: Cerambycidae) in pine stands. Appl Entomol Zool 48:213-221. https://doi.org/10.1007/s13355-013-0175-5

61. Svacha P, Lawrence JF (2014) 2.4 Cerambycidae Latreille, 1802. In: Richard AB, Beutel RG (eds) Handbook of Zoology, Arthropoda: Insecta. Coleoptera (Beetles). Morphology and systematic (Phytophaga), vol 3. Walter de Gruyter, Berlin/Boston, pp 16-177

62. Toledo VH, Noguera FA, Chemsak JA, Hovore FT, Giesbert EF (2002) The cerambycid fauna of the tropical dry forest of "El Aguacero," Chiapas, México (Coleoptera: Cerambycidae). Coleopterists Bulletin 56(4):515-532. https://doi.org/10.1649/0010-065X(2002)056[0515:TCFOTT]2.0.CO;2

63. Ulyshen MD (2011) Arthropod vertical stratification in temperate deciduous forests: Implications for conservation-oriented management. For Ecol Manage 261(9):1479-1489.

https://doi.org/10.1016/j.foreco.2011.01.033

64. Ulyshen MD (2016) Wood decomposition as influenced by invertebrates. Biol Rev 91:70-85. https://doi.org/10.1111/brv.12158

65. Ulyshen MD, Hanula JL (2007) A comparison of the beetle (Coleoptera) fauna captured at two heights above the ground in a North American temperate deciduous forest. Am Midl Nat 158:260-278. https://doi.org/10.1111/brv.12158 
66. Ulyshen MD, Horn S, Hanula JL (2010) Response of beetles (Coleoptera) at three heights to the experimental removal of an invasive shrub, Chinese privet (Ligustrum sinense), from floodplain forests. Biol Invasions 12:1573-1579. https://doi.org/10.1007/s10530-009-9569-2

67. Ulyshen MD, Sheehan TN (2019) Trap height considerations for detecting two economically important forest beetle guilds in southeastern US forests. J Pest Sci 92(1):253-265. https://doi.org/10.1007/s10340-017-0883-7

68. Uuttera J, Maltamo M, Kuusela K (1996) Impact of forest management history on the state of forests in relation to natural forest succession - Comparative study, north Karelia, Finland vs Republic of Karelia, Russian Federation. For Ecol Manage 83(1):71-85. https://doi.org/10.1016/03781127(95)03698-9

69. Vance CC, Kirby KR, Malcolm JR, Smith SM (2003) Community composition of longhorn beetlesed beetles (Coleoptera: Cerambycidae) in the canopy and understorey of sugar maple and white pine stands in southcentral Ontario. Environ Entomol 32:1066-1074. https://doi.org/10.1603/0046-225X32.5.1066

70. Wang J, Yang GJ, Yue YL, Zhang DZ (2016) Faunal composition and vertical distribution characteristics of Cerambycidae in Helan Mountain. Journal of Environmental Entomology 38(6):1154-1162 (in Chinese)

71. Wang Q, Adiku S, Tenhunen J, Granier A (2005) On the relationship of NDVI with leaf area index in a deciduous forest site. Remote Sens Environ 94:244-255. https://doi.org/10.1016/j.rse.2004.10.006

72. Weiss M, Didham RK, Procházka J, Schlaghamerský J, Basset Y, Odegaard F, Tichechkin A, Schmidl J, Floren A, Curletti G, Aberlenc HP, Bail J, Barrios H, Leponce M, Medianero E, Fagan LL, Corbara B, Gizek $L$ (2019) Saproxylic beetles in tropical and temperate forests - A standardized comparison of vertical stratification patterns. For Ecol Manage 444:50-58. https://doi.org/10.1016/j.foreco.2019.04.021

73. Weiss M, Procházka J, Schlaghamerský J, Cizek L (2016) Fine-scale vertical stratification and guild composition of saproxylic beetles in lowland and montane forests: similar patterns despite low faunal overlap. PLoS ONE 11:e0149506. https://doi.org/10.1371/journal.pone.0149506

74. Wende B, Gossner MM, Grass I, Arnstadt T, Hofrichter M, Floren A, Linsenmair KE, Weisser WW, Steffan-Dewenter I (2017) Trophic level, successional age and trait matching determine specialization of deadwood-based interaction networks of saproxylic beetles. Proceedings. Biological sciences 284. https://doi.org/10.1098/rspb.2017.0198

75. Yang RG, Huang JH, Zhou PN, Ban DX, Xie H, Li XL (2015) Study on diversity of Cerambycidae in Damingshan Nature $\mathrm{I}^{1} / 4^{2}$ eserve, Guangxi. Journal of Environmental Entomology 37(6):1133-1140 (in Chinese)

76. Yang ZQ, Tang YL, Jiang J, Wang XY, Tang H, Lu J, Gao Y (2012) Population-keeping mechanism of the parasitoid Dastarcus helophoroides (Coleoptera: Bothrideridae) of Massicus raddei (Coleoptera: Cerambycidae) in oak forest. Acta Ecol Sin 32(24):7764-7773 (in Chinese)

77. Yotkham S, Suttiprapan P, Likhitrakarn N, Sulin G, Srisuka W (2021) Biodiversity and Spatiotemporal Variation of Longhorn Beetles (Coleoptera: Cerambycidae) in Tropical Forest of Thailand. Insects 12(1):45. https://doi.org/10.3390/insects12010045 
Figures

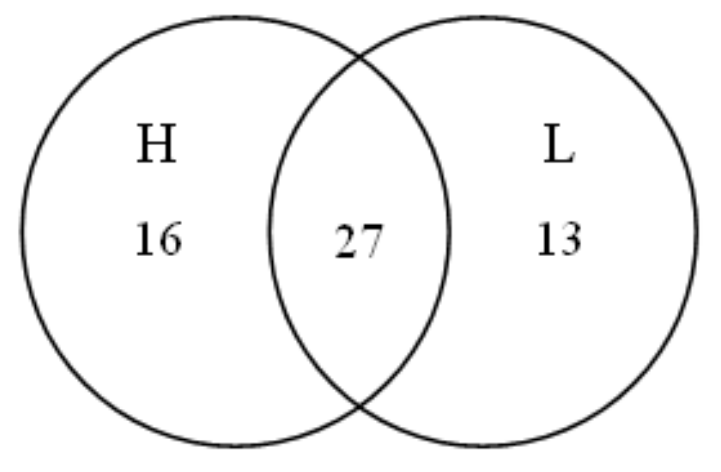

a

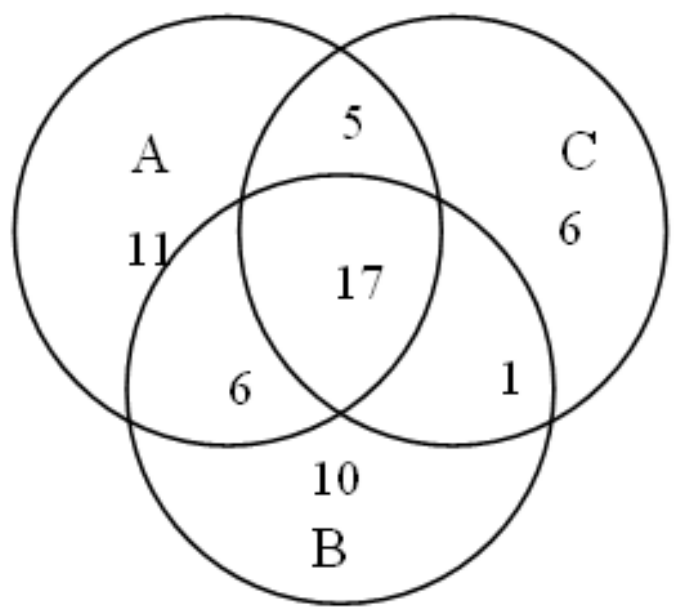

$\mathrm{b}$

Figure 1

Richness in the canopy $(\mathrm{H})$ and bottom layer $(\mathrm{L})(\mathrm{a})$ and on the ridge $(\mathrm{A})$, southern slope $(\mathrm{B})$, and northern slope (C) (b)

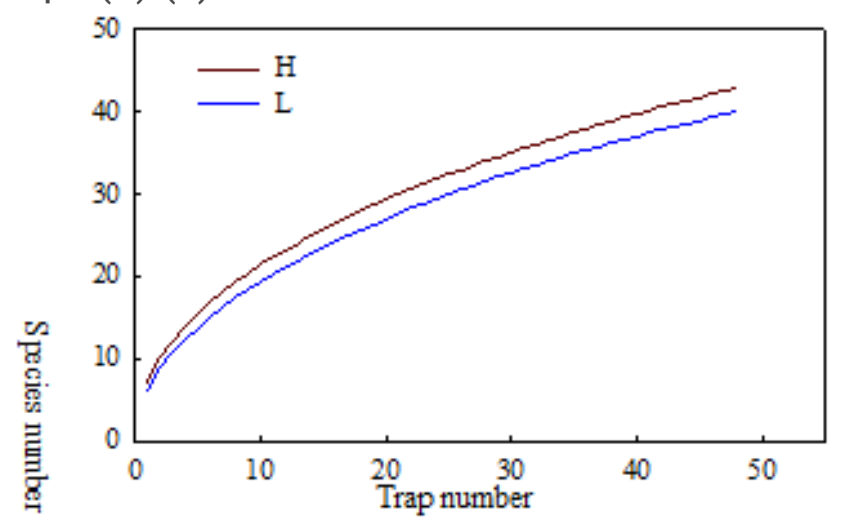

a

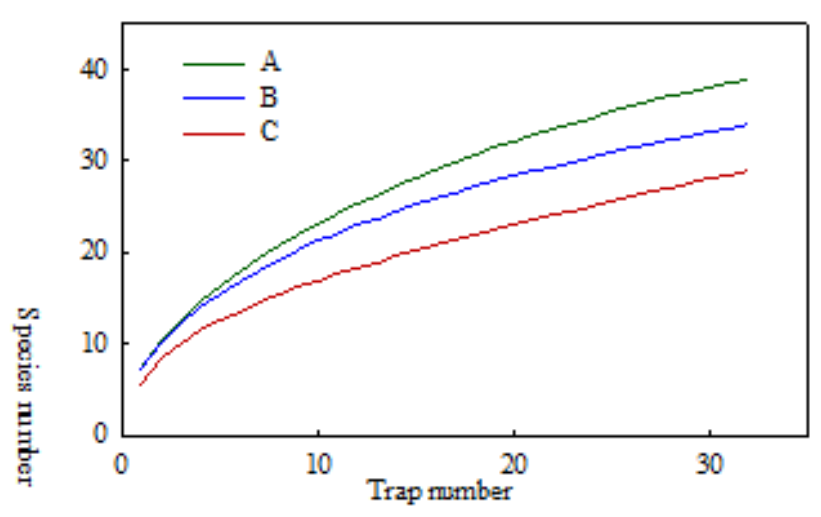

b

Figure 2

Sample-based rarefaction curves for the canopy $(H)$ and bottom layer $(L)(a)$, ridge $(A)$, southern slope $(B)$, and northern slope $(C)(b)$ 
a
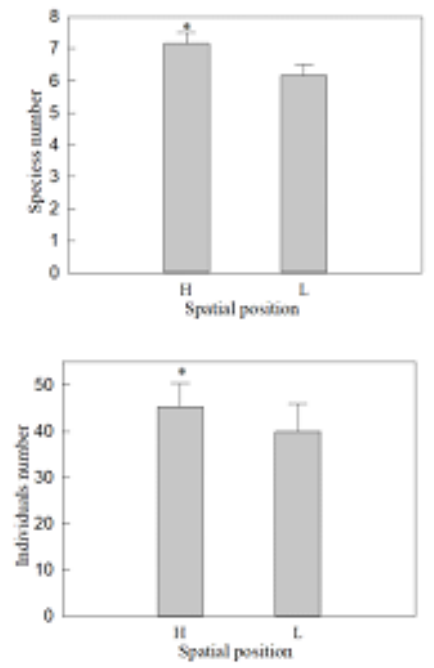

$\mathrm{b}$
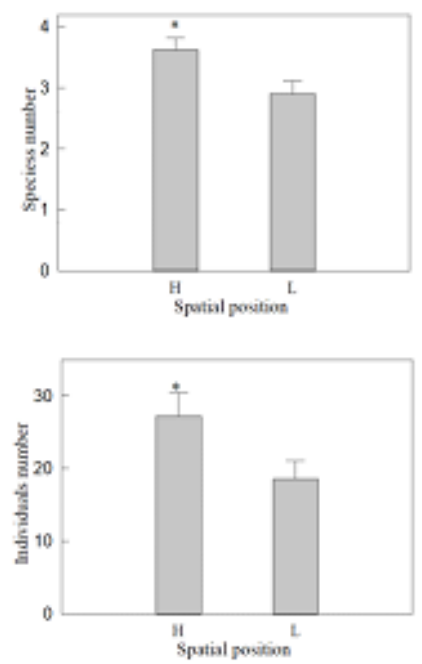

$\mathrm{c}$
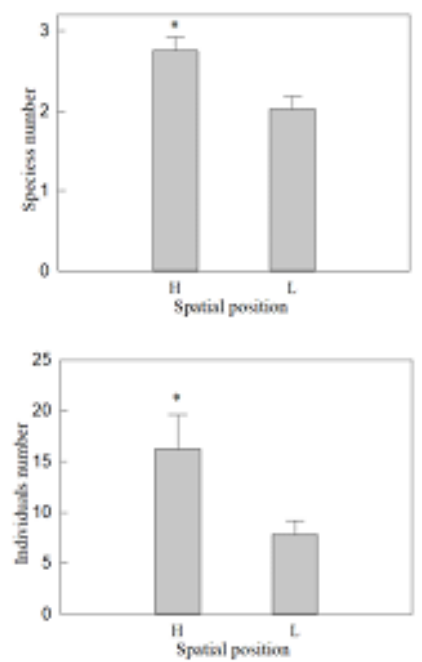

d
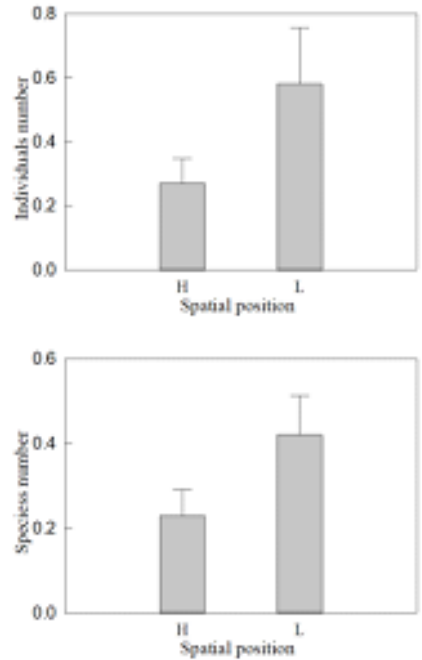

Figure 3

The richness and abundance of Cerambycidae (a), Cerambycinae (b), Lamiinae (c), and Lepturinae (d) in the canopy and the bottom
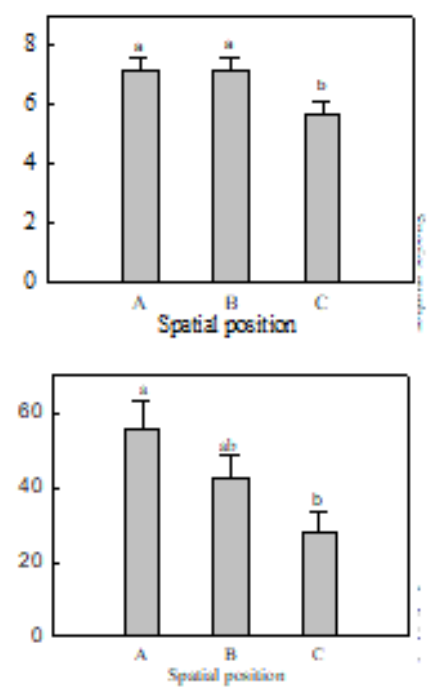

b
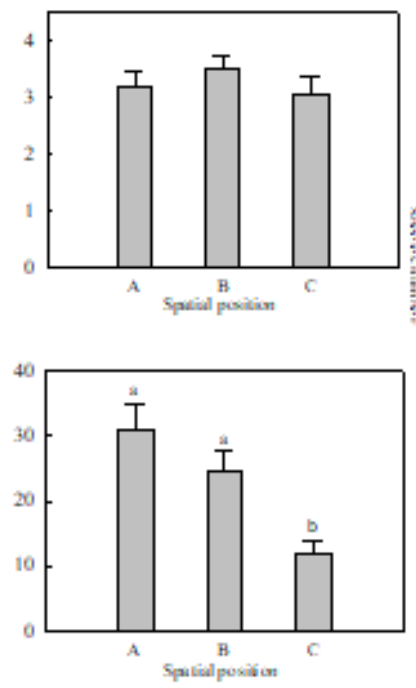

$\mathrm{c}$
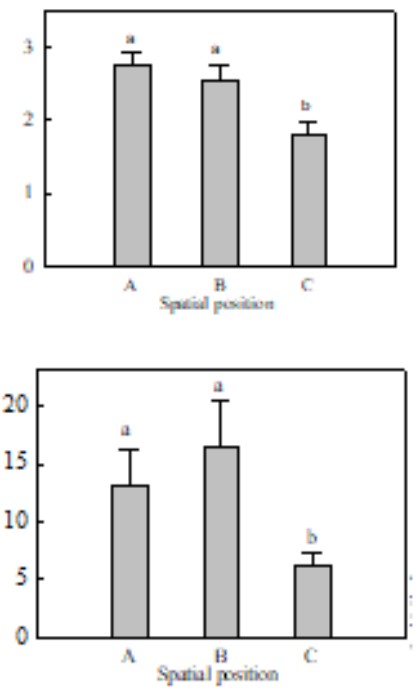

d
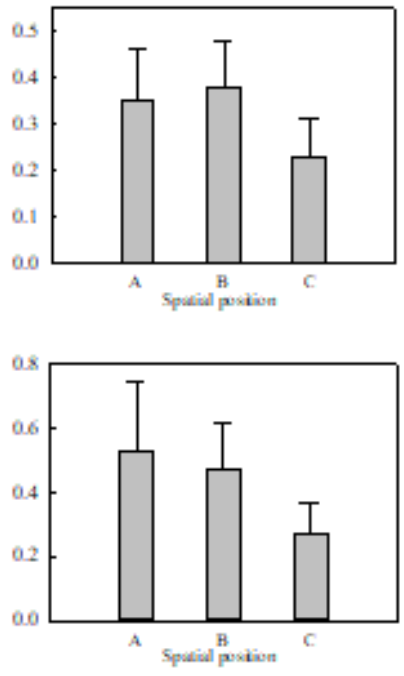

Figure 4

The richness and abundance of Cerambycidae (a), Cerambycinae (b), Lamiinae (c), and Lepturinae (d) on the ridge, southern slope, and northern slope 


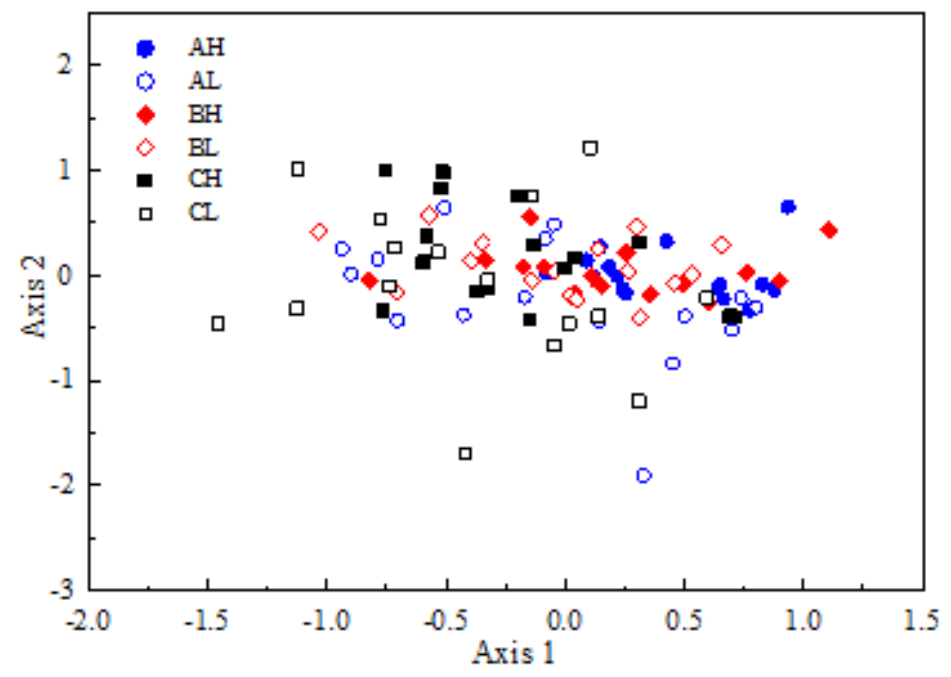

Figure 5

Non-metric multidimensional scaling ordination of longhorn beetles at two vertical heights $(H, L)$ and three positions (A, B, C) represented by different symbols and colors
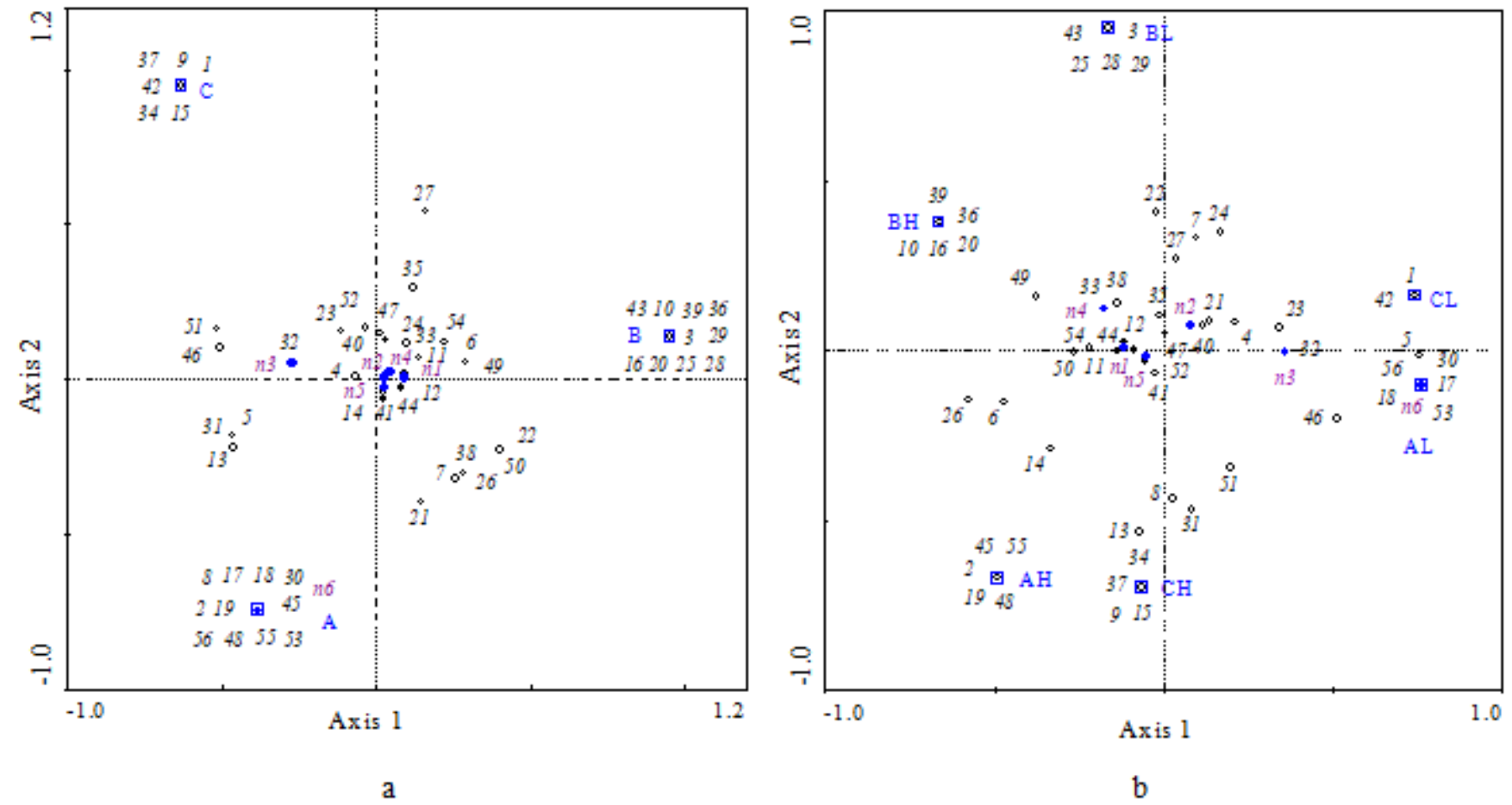

Figure 6

Correspondence analysis of 6 subfamilies and 56 species of longhorn beetles with the ridge (A), southern slope (B), and northern slope (C) (a), ridge canopy (AH), southern slope canopy (BH), northern slope (CH),

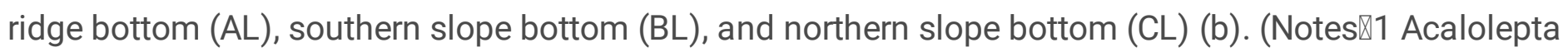
fraudatrix (Bates), 2 Acanthocinus griseus (Fabricius), 3 Anoplophora glabripennis Breuning, 4 Eumecocera impustulata (Motschulsky), 5 Eutetrapha metallescens (Motschulsky), 6 Exocentrus fisheri Gressitt, 7 Lamiomimus gottschei Kolbe, 8 Leiopus stillatus (Bates), 9 Menesia sulphuratasulphurata 
(Gebler), 10 Mesosa hirsute Bates, 11 Mesosa myopsmyops (Dalman), 12 Moechotypa diphysis (Pascoe), 13 Monochamus guttulatus (Gressitt), 14 Neacanista tuberculipennis Gressitt, 15 Oplosia suvorovi (Pic), 16 Pterolophia angusta (Bates), 17 Pterolophia rigida (Bates), 18 Rhopa loscelisunifasciatus Blessig, 19 Ropica dorsalis Schwarzer, 20 Egesina bifasciana Matsushita, 21 Anastrangalia sequensi (Reitter), 22 Gaurotes ussuriensis Blessig, 23 Leptura arcuata Panzer, 24 Macroleptura thoracica (Creutzer), 25 Macropidonia ruficollis (Pic), 26 Pedostrangalia femoralis (Motschulsky), 27 Pidonia gibbicollis (Blessig), 28 Rhagium inquisitor japonicum (Bates), 29 Stictoleptura succedanea (Lewis), 30 Stictoleptura variicomis (Dalman), 31 Anoplodera cyanea (Gebler), 32 Prionus insularis Motschulsky, 33 Distenia gracilis (Blessig), 34 Amarysius sanguinipennis (Blessig), 35 Anaglyptus colobotbeoides (Bates), 36 Chlorophorus motschulskyi (Ganglbauer), 37 Chlorophorus sexmaculatus (Motschulsky), 38 Chlorophorus sulcaticeps Pic, 39 Chlorophorus tohokensis Hayash, 40 Cyrtoclytus capracapra (Germar), 41 Massicus raddei (Blessig), 42 Obrium obscuripenne Pic, 43 Oupyrrhidium cinnabarium cinnabarium (Blessig), 44 Plagionotus pulcherpulcher (Blessig), 45 Purpuricenus sideriger Fairmaire, 46 Rhaphuma acutivittis (Kraatz), 47 Rhaphuma gracilipes (Faldermann), 48 Rhopalopus speciosus Plavilstshikov, 49 Trichoferus campestris (Faldermann), 50 Trichoferus guerryi (Pic), 51 Xylotrechus clarinus Bates, 52 Xylotrechus cuneipenniscuneipennis (Kraatz), 53 Xylotrechus pyrrhoderus Bates, 54 Xylotrechus rufilius Bates, 55 Chloridolum sieversi (Ganglbauer), 56 Arhopalus rusticus (Linnaeus), n1 Lamiinae, n2 Lepturinae, n3 Prioninae, n4 Disteniinae, n5 Cerambycinae, n6 Aseminae.) 